\title{
What makes a medical school socially accountable? A qualitative thematic review of the evaluation of social accountability of medical schools in the Eastern Mediterranean Region
}

\author{
Mohamed Abdalla , ${ }^{1}$ Mohamed Taha, ${ }^{2}$ Majed Wadi ${ }^{3}$ and Husameldin Khalafalla ${ }^{4,5}$
}

${ }^{1}$ School of Medicine, Faculty of Education and Health Sciences, University of Limerick, Limerick, Ireland. ${ }^{2}$ College of Medicine and Medical Education Centre, University of Sharjah, United Arab Emirates (Correspondence to: Mohamed Taha: mtaha@sharjah.ac.ae). ${ }^{3}$ Department of Medical Education, College of Medicine, Qassim University, Saudi Arabia. ${ }^{45}$ Department of Family and Community Medicine, Faculty of Medicine, Jazan University, Saudi Arabia, ${ }^{5}$ Faculty of Health, Medicine, and Life Sciences, Maastricht University, Maastricht, Netherlands

\begin{abstract}
Background: The World Health Organization Regional Office for the Eastern Mediterranean Region established social accountability as one of its strategic directions for medical education in 2015, and individual countries have been contributing to ongoing social accountability endeavours.

Aims: This study aimed to identify themes related to compliance with social accountability concepts in the countries of the Eastern Mediterranean Region (EMR) based on published papers

Methods: Thematic analysis of qualitative studies was done following a scoping review of published papers in the EMR over the period 1995-2021. CINAHL, Google Scholar, PubMed, Scopus, and Web of Sciences were searched along with a manual search for articles from reference lists. The Enhancing Transparency in Reporting the Synthesis of Qualitative Research ENTREQ statement guided the review.

Results: The reviewed studies $(n=3)$ were from 3 countries in the EMR: Egypt, Saudi Arabia, and Sudan. These studies identified 7 key themes: mission and governance, communication with stakeholders, a community-oriented and community-based curriculum, provision of health services, responding to emerging community health needs, impactful faculty and student research and gaps to be addressed.

Conclusions: Despite the call to reorient health profession schools to be responsive to the community and health system needs, only 3 countries in the EMR reported their efforts to move towards social accountability. Urgent action needs to be taken by medical education leaders in the Region to support colleges in their compliance with social accountability concepts.

Keywords: social accountability; social responsibility; community-based medical education; health professions education

Citation: Abdalla ME; Taha Mohamed H; Wadi M; Khalafalla H. What makes a medical school socially accountable? A qualitative thematic review of the evaluation of social accountability of medical schools in the Eastern Mediterranean Region. East Mediterr Health J. 2022;28(5):381-389. https://doi.org/10.26719/emhj.22.016

Received: 10/06/21; accepted: 14/10/21

Copyright (c) World Health Organization (WHO) 2022. Open Access. Some rights reserved. This work is available under the CC BY-NC-SA 3.0 IGO license (https://creativecommons.org/licenses/by-nc-sa/3.o/igo).
\end{abstract}

\section{Introduction}

Social accountability is considered a relatively new direction in health professions education. It was first defined by the World Health Organization (WHO) in 1995 (1), followed by the publication of the 10 strategic directions for social accountability in the Global Consensus for Social Accountability of Medical Schools in 2010 (2). Since then, medical schools have been documenting their work to demonstrate compliance with the concept of social accountability and efforts to satisfy community health needs (3). Social accountability is in the higher block in the continuum of social obligation of medical schools published by Boelen et al. in 2012, in which 3 levels were outlined: social responsibility, social responsiveness and social accountability (4).

There are several approaches that medical schools can take in moving towards social accountability; some engage in community-based medical education activities such as offering a package of courses in anthropology, epidemiology and public health, focusing on poverty and health disparities (5). Another critical aspect in the move towards social accountability that has been defined in previous research is the collaboration between medical schools and key health actors, such as health policy-making bodies, health care organizations, professional associations, other health care professional schools and community representatives (6). Although several frameworks exist to measure the compliance of medical schools with the concept of social accountability, such as the WHO social accountability Grid (1), the Conceptualization, Production and Usability (CPU) model (4), and the Training for Health Equity network model/ framework (THEnet) (7), to the best of our knowledge there are no studies comparing those different frameworks.

As part of the social accountability movement at a global level, the WHO Regional Office for the Eastern Mediterranean established social accountability as one 
of its strategic directions for medical education in 2015 (8), and individual countries have also been contributing to ongoing social accountability endeavours (9). However, despite the international call to reorient medical schools to become socially accountable, currently, there is limited reporting on the compliance of medical schools with social accountability in the Eastern Mediterranean Region. Accordingly, this review aimed to document what makes medical schools socially accountable in the Region.

The purpose of this study was to identify themes related to compliance with social accountability concepts in the countries of the EMR based on published papers.

\section{Methodology}

\section{Design}

The authors conducted a scoping review of the literature and then a thematic synthesis using the review methods suggested by Ring et al. (10). The reporting of this review has been guided by the ENTREQ statement (11).

\section{Search methods}

The search involved the following databases: CINAHL, Google Scholar, PubMed, Scopus, and Web of Sciences. The following search string was used: "social accountability" OR "Eastern Mediterranean Region" OR "medical schools" OR "EMRO region" OR "health professions education" OR "each of the individual EMR country names (e.g. Egypt, Sudan, etc.)" OR "compliance" OR "commitment" OR "evaluation" OR "assessment".

\section{Inclusion/exclusion criteria}

The search strategy was refined to articles published in English between 1995 and 2021. The final searches exported results to a reference management system and removed duplicate results. Only original articles and qualitative studies from the EMR were included in this review.

\section{Search outcome}

The initial search retrieved 162 articles, and a further 5 articles were identified through other sources. Figure 1 shows the search outcome.

\section{Study design}

The first and second authors (MEA and MHT) summarized the characteristics of each study to offer contextual information on author, date, country, study design and method of analysis. The aim of each study and evidence of reflexivity were recorded. The first 2 authors (MEA and MHT) appraised all 3 articles while the third and fourth authors (MW and HK) reviewed and coded a sub-sample of the included papers. For the 3 studies meeting the search criteria, the methodology, findings, and discussion sections of the papers were reviewed using the qualitative assessment criteria outlined by Walsh and Downe (12) and Balaam et al. (13).

\section{Data extraction and synthesis}

Authors MEA and MHT undertook manual, line-by-line coding of the text after reading each study several times. They used free codes annotated in the margins of the article. The coding was commenced inductively, where new and emerging codes were repeatedly compared and contrasted. The free codes generated from the manual coding were consequently arranged into descriptive themes.

Authors HK and MW repeated this process. Finally, when open coding was complete, and descriptive codes were generated from all 3 papers, all authors discussed and analytically interpreted the descriptive themes to further develop analytical themes.

\section{Ethical considerations}

As the nature of the study does not involve interaction with humans or identifiable information, no ethical approval was required.

\section{Results}

\section{Overview}

The review included 3 articles from 3 countries, 3 universities in the EMR: Faculty of Medicine Suez Canal University (FOM/SCU) in Egypt (14), College of Medicine Qassim University (COM/QU) in Saudi Arabia (15), and Faculty of Medicine University of Gezira (FOM/UofG) in Sudan (16).

Table 1 shows a summary of the findings of the 3 studies included in the review. They identified 7 key themes documenting the journey towards social accountability. These are illustrated in the following sections.

\section{Theme 1: Mission and governance}

From the content of the analysis, the missions in the 3 medical schools mentioned the importance of attending to society's health needs. Both FOM/SCU and COM/QU indicated the existence of policies to do a health needs assessment, while only FOM/SCU mentioned the existence of a strategic plan based on a needs assessment.

\section{Theme 2: Communication with stakeholders}

All 3 colleges mentioned ongoing communication with stakeholders and participation in councils and committees in which stakeholders were represented, including the Ministry of Health and the community. The 3 colleges indicated that their faculty members held positions in the Ministry of Health.

\section{Theme 3: Community-oriented and community- based curriculum}

All 3 colleges follow community-oriented medical education, community-based education, problem-based learning, integration of sciences and early clinical exposure strategies. However, none of them mentioned the development of learning outcomes based on society's health needs. Only the study from FOM/UofG reported that 


\section{Figure 1 Flow diagram of literature search results}
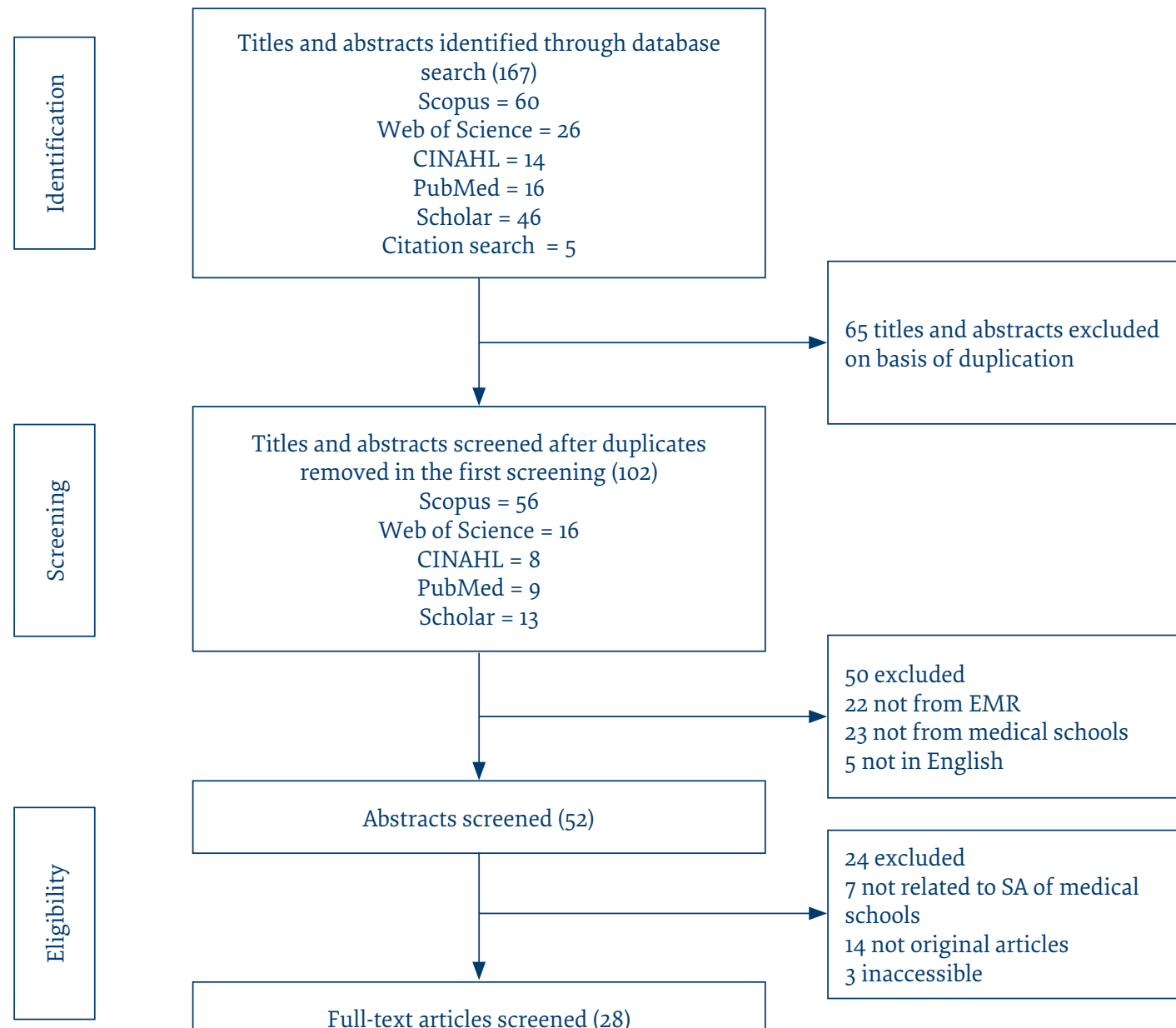

24 excluded

7 not related to SA of medical

schools

14 not original articles

3 inaccessible

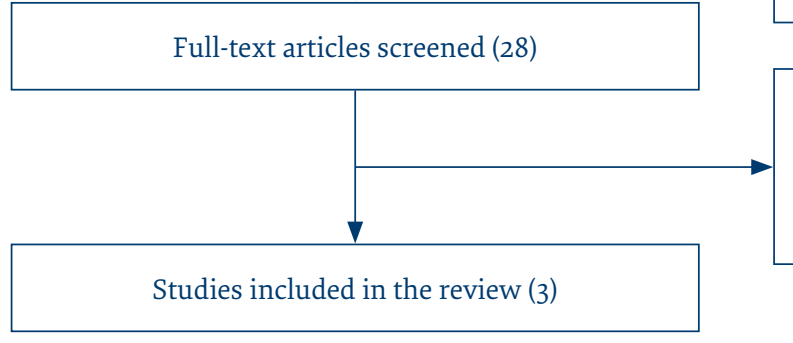

25 excluded

Not assessing compliance with

social accountability(22)

Not qualitative studies (3)

they had considered the community's opinion on the assessment of students and programme evaluation. None of the 3 colleges mentioned a specific student admission policy from underserved areas.

In terms of curriculum delivery, a study from FOM/ UofG reported the experience of an interdisciplinary field training, research and rural development programme in which groups of 10-15 students were assigned to one village and carried out a group project, supervised by a group of staff members. Similarly, a study from FOM/ SCU reported that students were exposed to patients and assigned to work with multidisciplinary health teams in their first days at medical school. Examples of community-based activities training were not reported from the study from COM/QU.

\section{Theme 4: Provision of health services}

In the service domain, the 3 medical schools made different contributions to health service provision. FOM/ SCU and COM/QU ran primary health care units providing health services to the local population. Faculty members from the 3 colleges were involved in the provision of health services at different levels: FOM/SCU and FOM/UofG medical schools regularly participated with the Ministry of Health in training health professionals and engaging in joint health projects. In the FOM/SCU, an agreement was reached with the Ministry of Health, which entailed that university hospitals and Ministry of Health hospitals were jointly responsible for providing health services in the area. It was stated that the training of health professionals would be carried out at the university hospital. In contrast, the Gezira University study 
reported that the Ministry of Health had established the rural visiting consultant programme in collaboration with the FOM/UofG. Faculty staff consultants were to provide outreach services by attending outpatient clinics and performing surgical operations at hospitals in rural areas.

\section{Theme 5: Responding to emerging community health needs}

An example of a college's participation in community activities was reported in the study from FOM/UofG. The study reported:

"The medical school actively participates in outbreaks of any genuine community health problem by offering the community with the needed prevention and control measures via community courses at the family and community levels in collaboration with local health service providers and community-related sectors."

In considering a policy for systematically assessing the community's needs, the study from the FOM/SCU reported that the school had established a policy for systematically assessing the needs of the community.

\section{Theme 6: Impactful faculty and student research}

The study from FOM/UofG mentioned research examples that were used to improve health status in Gezira State Sudan. One example of the impact of research conducted by the University of Gezira staff on health decisionmaking was the recommendation for the second dose of the measles vaccine (17). In addition, the findings from the study conducted by COM/QU indicated that the research centre had documented research outcomes, and Qassim University had developed key performance indicators. According to the study, research done by college staff had influenced policy change and several types of research had been conducted by COM/QU staff to address local community health system needs; some of these projects had been conducted jointly with Ministry of Health staff.

The study from FOM/SCU reported that research was directed toward community needs and problems in the community it serves, and provided several examples of these research studies $(18,19)$

\section{Theme 7: Gaps to be addressed}

Several gaps and challenges were reported in the 3 studies. The study from COM/QU reported that to transition from the traditional community-oriented medical education path to the full spectrum of social accountability, a college must engage with stakeholders more frequently. The college must also pay special attention to the following areas: regional health issues, not just health system/ care issues, social determinants of health issues and cost-effectiveness in both education and research. In contrast, the study from FOM/QU reported that 2 main areas needed to be addressed in the faculty's progress towards social accountability: the cost-effectiveness of the research domain and planning for quality services. The study from the FOM/SCU did not report any particular obstacles to being fully socially accountable.

\section{Findings related to quality appraisal of the reviewed papers}

The main methodological limitations of the studies reviewed were that they relied on the analysis of existing documents and the views of college leaders and staff members. Additionally, interviews were conducted on only a small number of interviewees. Detailed limitations are shown in Table 1.

\section{Discussion}

This review aimed at documenting what makes medical schools socially accountable in the EMR. We identified 7 key themes in the studies that were reviewed.

The first theme sheds light on the significance of drafting a medical school mission. In this review, the 3 medical schools mentioned the social health needs in their mission. The Global Consensus for Social Accountability of Medical Schools indicate that socially accountable medical schools should have missions that respond to and anticipate the health needs of a society (2). Boelen and Dharmasi state that the direction towards social accountability begins with a mission that addresses society's health needs (4). It was found that mentioning the support of the communities served by medical schools was linked to young medical schools (20); the 3 medical schools in this review were established after 1975.

The second theme is related to the governance of medical schools and the importance of relationships and communication with stakeholders. The results of this review reflect that all 3 colleges mentioned ongoing communication with stakeholders and participation in councils and committees in which stakeholders, including the Ministry of Health and the community, were represented. These findings are consistent with some good practices held by socially accountable medical schools, such as those adopted by the medical school of Tours in the Loire Valley in France. This college regularly invites representatives of all prominent health actors, from health authorities to citizens from the region (Region du Centre et du Val de Loire), which has a population of 3 million people, to attend meetings in the school grounds (5).

The third theme highlights the similarities between the 3 medical schools in adopting community-based medical education, an integrated curriculum, early exposure to clinical training for the students, and the adoption of problem-based learning. These findings have been reported by the distinguished socially accountable medical school, Hull York Medical School, which was awarded the ASPIRE Social Accountability Award in 2013 (21). However, none of the 3 medical schools reviewed reported contributions to the community that the colleges served. In contrast, the graduates of Hull York Medical School favour general practice far more than those from schools with less exposure to primary or community care 


\begin{tabular}{|c|c|c|c|c|c|c|c|}
\hline Study title & Author & Country & $\begin{array}{l}\text { Aim of the } \\
\text { study }\end{array}$ & $\begin{array}{l}\text { Framework/ } \\
\text { model used }^{\mathrm{a}}\end{array}$ & $\begin{array}{l}\text { Data } \\
\text { collection } \\
\text { methods }\end{array}$ & $\begin{array}{l}\text { School on } \\
\text { SA scale }\end{array}$ & Limitations \\
\hline $\begin{array}{l}\text { Is our medical } \\
\text { school socially } \\
\text { accountable? } \\
\text { The case of } \\
\text { Faculty of } \\
\text { Medicine, } \\
\text { Suez Canal } \\
\text { University }\end{array}$ & $\begin{array}{l}\text { Hosny et } \\
\text { al., } 2015\end{array}$ & Egypt & $\begin{array}{l}\text { To report } \\
\text { internal } \\
\text { evaluation, using } \\
\text { the CPU model, } \\
\text { and discuss } \\
\text { where Suez } \\
\text { Canal Medical } \\
\text { School stands } \\
\text { with respect to } \\
\text { being a proactive } \\
\text { socially } \\
\text { accountable } \\
\text { school. }\end{array}$ & $\mathrm{CPU}$ & $\begin{array}{l}\text { Interviews } \\
\text { and document } \\
\text { review }\end{array}$ & $\begin{array}{l}\text { The college } \\
\text { can fulfil } \\
\text { a socially } \\
\text { accountable } \\
\text { mandate } \\
\text { in the near } \\
\text { future }\end{array}$ & $\begin{array}{l}\text { No mention of a self-reported } \\
\text { study or a qualitative study design. } \\
\text { Small sample size of interviewees } \\
\text { with no justification,andsample } \\
\text { from a single institution limit } \\
\text { generalizability. } \\
\text { Quotes from the interviews are not } \\
\text { published. } \\
\text { No mention of qualitative data } \\
\text { analysis. } \\
\text { Methods of analysis not stated. } \\
\text { No mention of the reflexive } \\
\text { process, which limits the } \\
\text { dependability of the findings. }\end{array}$ \\
\hline $\begin{array}{l}\text { Assessment } \\
\text { of the social } \\
\text { accountability } \\
\text { of the faculty } \\
\text { of medicine at } \\
\text { the University } \\
\text { of Gezira, } \\
\text { Sudan }\end{array}$ & $\begin{array}{l}\text { Elsanousi } \\
\text { et al., } 2016\end{array}$ & Sudan & $\begin{array}{l}\text { To determine } \\
\text { whether the } \\
\text { University of } \\
\text { Gezira faculty } \\
\text { of medicine is } \\
\text { progressing } \\
\text { towards being } \\
\text { a fully socially } \\
\text { accountable } \\
\text { medical school. }\end{array}$ & WHO SA grid & $\begin{array}{l}\text { Document } \\
\text { review }\end{array}$ & $\begin{array}{l}\text { Social } \\
\text { responsive }\end{array}$ & $\begin{array}{l}\text { Self-reported study. } \\
\text { Includes only document review } \\
\text { and review of students' activities. } \\
\text { No mention of qualitative data } \\
\text { analysis. } \\
\text { Methods of analysis not stated. } \\
\text { No mention of the reflexive } \\
\text { process, which limits the } \\
\text { dependability of the findings. }\end{array}$ \\
\hline $\begin{array}{l}\text { Commitment } \\
\text { towards a } \\
\text { better future } \\
\text { for medical } \\
\text { education in } \\
\text { Saudi Arabia: } \\
\text { the efforts of } \\
\text { the College } \\
\text { of Medicine } \\
\text { at Qassim } \\
\text { University } \\
\text { to become } \\
\text { socially } \\
\text { accountable }\end{array}$ & $\begin{array}{l}\text { Alresbish } \\
\text { et al., } 2020\end{array}$ & $\begin{array}{l}\text { Saudi } \\
\text { Arabia }\end{array}$ & $\begin{array}{l}\text { To assess } \\
\text { whether } \\
\text { the college } \\
\text { is a socially } \\
\text { accountable } \\
\text { medical school } \\
\text { and the steps } \\
\text { taken to achieve } \\
\text { that target. }\end{array}$ & $\begin{array}{l}\text { WHO SA grid } \\
\text { and CPU }\end{array}$ & $\begin{array}{l}\text { Document } \\
\text { review and } \\
\text { interviews }\end{array}$ & $\begin{array}{l}\text { Socially } \\
\text { responsible } \\
\text { and } \\
\text { responsive }\end{array}$ & $\begin{array}{l}\text { Study relies on the analysis of } \\
\text { existing documents and views of } \\
\text { college leaders and staff members. } \\
\text { A small interviewee sample size } \\
\text { with no justification, as well as } \\
\text { sample from a single institution, } \\
\text { limit generalizability. } \\
\text { No mention of the reflexive } \\
\text { process, which limits the } \\
\text { dependability of the findings. }\end{array}$ \\
\hline
\end{tabular}

The model/framework used in evaluating school compliance with social accountability.

$\mathrm{CPU}=$ Conceptualization, Production and Usability model.

(22). Another example from the University of New Mexico School of Medicine, which is a pioneering institute in social accountability worldwide, reported that in 2017 , a higher proportion of the senior medical students (30.2\%) matched in family medicine residencies than any of the other $141 \mathrm{MD}$-granting medical schools in the United States of America (23). In 2016, Boloen had said that the retention of graduates in underserved areas, the choice of a career as a primary care practitioner, and opportunities for practice in multi-professional teams are essential indicators that meaningfully reflect social accountability principles (5).

The fourth theme that emerged in this review highlights participation in community activities that were exemplified by FOM/UofG, which reported active contributions to outbreaks; FOM/SCU reported contributions to the prevention and behavioural involvement in mitigating patterns related to the hepatitis C virus endemicity in the Suez Canal area in 2012. Similar activities were reported by a well-known socially accountable medical school, the Northern Ontario School of Medicine. This medical school been engaging communities as active partners in designing and delivering educational programmes, focusing curricular content on the priority health needs of the population, and specifically aligning clinical placement opportunities with historically underserved settings (24).

The fifth theme identified refers to the impactful faculty and student research: all 3 colleges reported having conducted research related to society's needs. The findings reported by the colleges align with socially accountable medical schools that are conducting research inspired by and responding to their own community and the Region's top health priorities. For example, the faculty of a similarly socially accountable medical school, the Memorial University of Newfoundland in Newfoundland, Canada, a large province (400 $000 \mathrm{~km}$ ) with a small population of 500000 , conducted groundbreaking genetic research in arrhythmogenic ventricular cardiomyopathy, a disease in which the first symptom 
is usually sudden death from ventricular fibrillation in young men and women. The use of implantable defibrillator pacemakers in all family members was found to be effective in halting sudden deaths. The genetic puzzle was solved, and a genetic test for at-risk families was developed to determine who needed a defibrillator $(21,25)$.

Comparing the status of the 3 colleges included in this study to the other colleges that have been recognized as socially accountable medical schools - the 10 awardwinning social accountability ASPIRE medical schools the 3 colleges need to demonstrate the following features.

- In curriculum planning and the admission of students, the curriculum needs to be reviewed for relevance to the cultural context as well as the community, national and regional priority health needs. Moreover, the admission of students should include an appropriate demographic mix from the region and community served by the medical school. Colleges need to show the integration of the concept of social accountability into day-to-day management activities and explicitly demonstrate the concept in the missions and mandate of the college.

- At the curriculum delivery level, community-based learning for underserved groups of the population needs to be reinforced; moreover, integration of social accountability concepts into the curriculum needs to be considered (26), and clinical learning experiences should be implemented that reflect the geographical, social and cultural diversity of the community region. Alumni and graduates should be followed to determine their speciality preference towards family and community medicine. Their positive impact on the community that they served should be considered.

For research, the 3 colleges need to show that their research is inspired by and responds to the priority health needs of the medical school's community, region and nation. It should facilitate participation in knowledge translation and mobilization (5,27-30).
One of the limitations of this review is that it reported the findings presented only in the published work of the colleges related to the concepts of social accountability in the form of a qualitative design. However, several studies have shown that some of these colleges greatly impacted the community they served. An example of this is the FOM/UofG Safe Maternity initiative, which led to a remarkable reduction in the maternal mortality rate from 469 per 100000 live births in 2005 to 57 in 2014 and neonatal mortality rate in Gezira state from 43.0 per 1000 live births in 2005 to 11.3 per 1000 in 2014 (31). Another great effort advanced by the same medical school, the Gezira model of in-service family medicine training, successfully recruited 207 candidates in its first cohort, providing health services in 158 centres, 84 of which had never previously been served by a doctor $(32,33)$.

The FOM/SCU, moreover, played an important role in eradicating endemic parasitic skin diseases in collaboration with the University School of Veterinary Medicine (34). Nevertheless, 20 years later, the community that it served had not identified endemic parasitic diseases as a priority health need.

The second limitation of this review is that it reported that the primary sources of the data in the 3 articles were self-reporting. As a result, it did not tap into several other aspects of social accountability, including the stakeholders of these colleges.

\section{Conclusion}

The studies included in this review documented the compliance of 3 medical schools in the Eastern Mediterranean Region with the concept of social accountability. Some efforts need to be exerted by these colleges in the education, research and community services domain to move toward full social accountable medical schools, and medical education leaders must take urgent action in the EMR to help the medical colleges to comply with social accountability concepts.

Funding: None.

Competing interests: None declared.

\section{Comment une école de médecine peut-elle être socialement responsable? Analyse thématique qualitative de l'évaluation de la responsabilité sociale dans les écoles de médecine de la Région de la Méditerranée orientale}

\section{Résumé}

Contexte: Le Bureau régional de l'Organisation mondiale de la Santé pour la Méditerranée orientale a désigné la responsabilité sociale comme l'une de ses orientations stratégiques pour l'enseignement médical en 2015 ; par ailleurs, certains pays ont contribué aux efforts en cours dans ce domaine.

Objectifs : La présente étude visait à identifier les thèmes liés à la conformité aux concepts de responsabilité sociale dans les pays de la Région de la Méditerranée orientale sur la base des articles publiés.

Méthodes: L'analyse thématique des études qualitatives a été réalisée suite à une étude exploratoire des articles publiés dans la Région de la Méditerranée orientale sur la période 1995-2021. Des recherches ont été effectuées dans CINAHL, Google Scholar, PubMed, Scopus et Web of Sciences, parallèlement à une recherche manuelle d'articles dans les listes de référence. Le protocole ENTREQ (Enhancing Transparency in Reporting the Synthesis of Qualitative Research) a orienté l'analyse. 
Résultats : Les études analysées $(n=3)$ provenaient de trois pays de la Région de la Méditerranée orientale : l'Arabie saoudite, l'Égypte et le Soudan. Ces études ont permis d'identifier sept thèmes clés: la mission et la gouvernance, la communication avec les parties prenantes, un programme d'études à orientation et à base communautaire, la prestation de services de santé, la réponse aux nouveaux besoins en matière de santé communautaire, les recherches à fort impact des professeurs et des étudiants ainsi que les lacunes à surmonter.

Conclusions: Malgré l'appel à réorienter les écoles de professions de santé pour qu'elles répondent aux besoins de la communauté et du système de santé, seuls trois pays de la Région de la Méditerranée orientale ont fait état de leurs efforts pour tendre vers la responsabilité sociale. Les responsables de l'enseignement médical de la Région doivent prendre des mesures urgentes pour aider les établissements à se conformer aux concepts de responsabilité sociale.

$$
\text { ما الذي ييعل كلية الطب مسؤولة اجتماعيًّا؟ استعر اض مواضيعي نوعي لتقييم المسؤولية الاجتحاعية في كليات الطب }
$$

محمد عبد الله، محمد طه، ماجد وادي، حسام الدين خلف الله

الخلفية: حدد المكتب الإقليمي لشرق المتوسط لمنظمة الصحة العالمية المسؤولية الاجتماعية باعتبارها أحد توجهاته الاستراتيجية للتعليم الطبي في

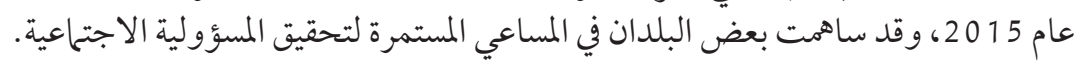

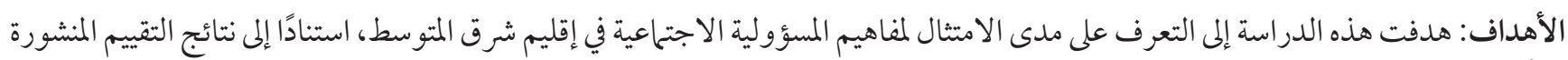

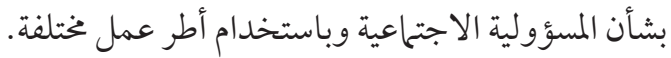

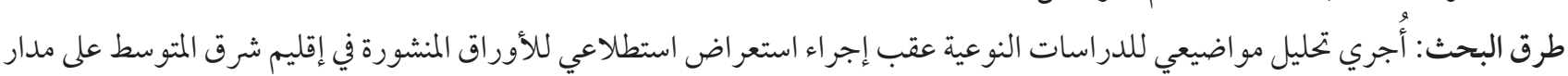

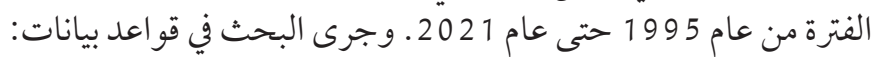

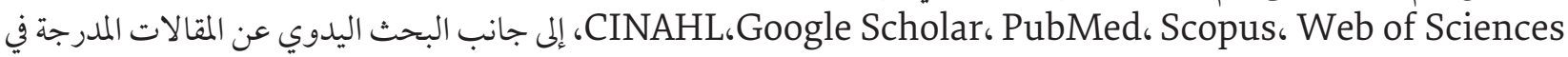

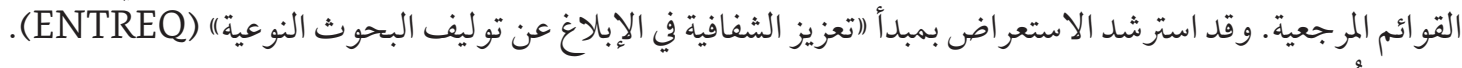

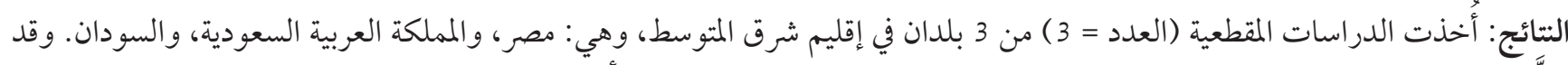

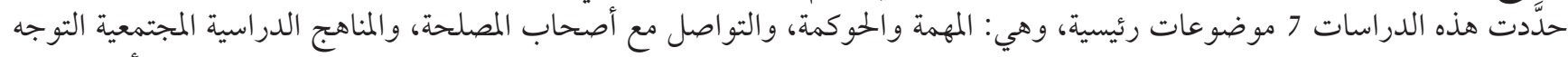

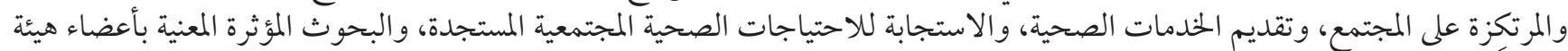

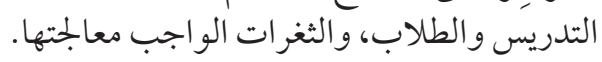

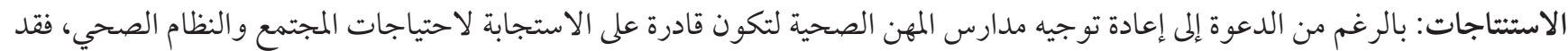

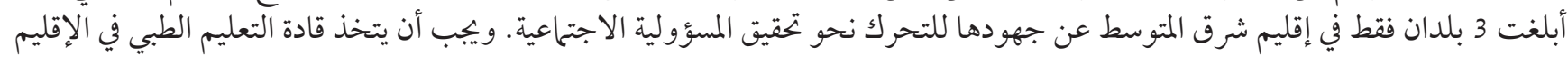
إجراءات عاجلة لدعم الكليات في امتثالها لمفاهيم المسؤولية الاجتمناعية.

\section{References}

1. Boelen C, Heck J. Defining and measuring the social accountability of medical schools. Geneva: World health Organization, Division of Development of Human Resources for Health; 1995 (https://apps.who.int/iris/handle/10665/59441, accessed 24 November 2021).

2. Global consensus for social accountability of medical schools. Hampton, Middlesex: World Federation for Medical Education; 2010 (http://healthsocialaccountability.sites.olt.ubc.ca/files/2011/06/11-06-07-GCSA-English-pdf-style.pdf, accessed 24 November 2021).

3. Walling E, Lachance E, Yeo L, Koepke K, Wasik A, Woollard R. Key drivers of social accountability in nine Canadian medical schools. Med Teach. 2021;43(2):182-8. doi:10.1080/0142159X.2020.1832205

4. Boelen C, Dharamsi S, Gibbs T. The social accountability of medical schools and its indicators. Educ Heal. 2012;25(3):180. Available from: http://www.educationforhealth.net/text.asp?2012/25/3/180/109785

5. Boelen C. Why should social accountability be a benchmark for excellence in medical education? Educ Médica. 2016 Jul;17(3):1015. https://doi.org/10.1016/j.edumed.2016.06.004

6. Boelen C, Woollard R. Social accountability: The extra leap to excellence for educational institutions. Med Teach. 2011;33(8):6149. doi:10.3109/0142159X.2011.590248

7. Larkins SL, Preston R, Matte MC, Lindemann IC, Samson R, Tandinco FD, et al. Measuring social accountability in health professional education: development and international pilot testing of an evaluation framework. Med Teach. 2013;35(1):32-45. doi:10.31 09/0142159X.2012.731106 
8. Review of medical education in the Eastern Mediterranean Region: challenges, priorities and a framework for action. Cairo: World Health Organization, Regional Office for the Eastern Mediterranean; 2015 (EM/RC62/3 Rev.1; https://vlibrary.emro. who.int/idr_records/review-of-medical-education-in-the-eastern-mediterranean-region-challenges-priorities-and-a-framework-for-action/, accessed 24 November 2021).

9. Abdalla ME, Boelen C, Osman WN. Development and evaluation of an online course about the social accountability of medical schools. J Taibah Univ Med Sci. 2019 Jun;14(3):241-5. https://doi.org/10.1016/j.jtumed.2019.03.004

10. Ring NA, Ritchie K, Mandava L, Jepson R. A guide to zsynthesizing qualitative research for researchers undertaking health technology assessments and systematic reviews (research report). Stirling: University of Stirling, NHS Quality Improvement Scotland (NHS QIS); 2011 (http://www.healthcareimprovementscotland.org/programmes/clinical_cost_effectiveness/programme_resources/synth_qualitative_research.aspx, accessed 24 November 2021).

11. Tong A, Flemming K, McInnes E, Oliver S, Craig J. Enhancing transparency in reporting the synthesis of qualitative research: ENTREQ. BMC Med Res Methodol. 2012;12(1):1-8. doi:10.1186/1471-2288-12-18

12. Walsh D, Downe S. Appraising the quality of qualitative research. Midwifery.

13. Balaam M, Akerjordet K, Lyberg A2006;22(2):108-19. doi:10.1016/j.midw.2005.05.004, Kaiser B, Schoening E, Fredriksen A, et al. A qualitative review of migrant women's perceptions of their needs and experiences related to pregnancy and childbirth. J Adv Nurs. 2013 Sep;69(9):1919- 30. doi:10.1111/jan.12139

14. Hosny S, Ghaly M, Boelen C. Is our medical school socially accountable? The case of Faculty of Medicine, Suez Canal University. Med Teach. 2015 Mar 13;37(Suppl. 1):S47-55. doi:10.3109/0142159X.2015.1006600

15. Alrebish SA, Taha MH, Ahmed MH, Abdalla ME. Commitment towards a better future for medical education in Saudi Arabia: the efforts of the college of medicine at Qassim University to become socially accountable. Med Educ Online. 2020;25(1). doi:10.1080/ 10872981.2019.1710328

16. Elsanousi S, Elsanousi M, Khalafallah O, Habour A. Assessment of the social accountability of the faculty of medicine at University of Gezira, Sudan. East Mediterr Heal J. 2016;22(4):258-66. doi:10.26719/2016.22.4.258

17. Elsanousi S, Babiker A. The emergence of measles among basic school children in Wad Medani, is a second dose of measles vaccine needed? Sudan J Paediatr. 2003;6(1):80-8 (http://www.sudanjp.com/?mno=105128, accessed 24 November 2021).

18. Abdulmajeed AA, Ismail MA, Nour-Eldein H. Research publications in medical journals (1992-2013) by family medicine authors-suez canal university-egypt. J Fam Med Prim care. 2014;3(4):368. doi:10.4103/2249-4863.148112

19. Halim WB, Khalil KA, Sobhy SA, Hasb-Allah SA. Prevalence of bronchial asthma among secondary schools students at Abu Khalifa village-Ismailia Governorate. Med J Cairo Univ. 2013;81(2) (file:///C:/Users/EA/AppData/Local/Temp/1337-2596-1-SM.pdf, accessed 24 November 2021).

20. Lewkonia RM. The missions of medical schools: the pursuit of health in the service of society. BMC Med Educ. 2001 Dec 18;1(1):4. doi:10.1186/1472-6920-1-4

21. Boelen C, Pearson D, Kaufman A, Rourke J, Woollard R, Marsh DC, et al. Producing a socially accountable medical school: AMEE Guide No. 109. Med Teach. 2016 Nov 9;38(11):1078-91. doi:10.1080/0142159X.2016.1219029

22. Adam J, Bore M, Childs R, Dunn J, Mckendree J, Munro D, et al. Predictors of professional behaviour and academic outcomes in a UK medical school: a longitudinal cohort study. Med Teach. 2015;37(9):868-80. doi:10.3109/0142159X.2015.1009023

23. Kaufman A, Roth PB, Larson RS, Ridenour N, Welage LS, Romero-Leggott V, et al. Vision 2020 measures University of New Mexico's success by health of its state. Am J Prev Med. 2015;48(1):108-15. doi:10.1016/j.amepre.2014.08.001

24. Strasser R, Worley P, Cristobal F, Marsh DC, Berry S, Strasser S, et al. Putting communities in the driver's seat: the realities of community-engaged medical education. Acad Med. 2015;90(11):1466-70. doi:10.1097/ACM.0000000000000765

25. Merner ND, Hodgkinson KA, Haywood AFM, Connors S, French VM, Drenckhahn J-D, et al. Arrhythmogenic right ventricular cardiomyopathy type 5 is a fully penetrant, lethal arrhythmic disorder caused by a missense mutation in the TMEM43 gene. Am J Hum Genet. 2008;82(4):809-21. doi:10.1016/j.ajhg.2008.01.01

26. Rourke J. Social accountability: a framework for medical schools to improve the health of the populations they serve. Acad Med. 2018;93(8):1120-4. doi:10.1097/ACM.0000000000002239

27. Woollard B, Boelen C. Seeking impact of medical schools on health: meeting the challenges of social accountability. Med Educ. 2012;46(1):21-7. doi:10.1111/j.1365-2923.2011.04081.x

28. Fenoll-Brunet MR, Harden RM. La excelencia en educación médica: ASPIRE. Educ Médica. 2015;16(2):109-15. doi:10.1016/j. edumed.2015.09.010

29. Barber C, van der Vleuten C, Leppink J, Chahine S. Social accountability frameworks and their implications for medical education and program evaluation: a narrative review. Acad Med. 2020 Dec 24;95(12):1945-54. doi:10.1097/ACM.0000000000003731

30. Miskeen E. Maternal mortality reduction in low-resource settings, a successful story of University of Gezira initiative for safe motherhood and childhood. Soc Innov J. 2020;4. (https://socialinnovationsjournal.com/index.php/sij/article/view/491, accessed 24 November 2021).

31. Mohamed KG, Hunskaar S, Abdelrahman SH, Malik EM. Scaling up family medicine training in Gezira, Sudan-a 2-year in-service master programme using modern information and communication technology: a survey study. Hum Resour Health. 2014;12(1):1-9. doi:10.1186/1478-4491-12-3 
32. Ahmed $\mathrm{MH}$, Abdalla ME, Taha $\mathrm{M}$. Why social accountability of medical schools in Sudan can lead to better primary healthcare and excellence in medical education? J Family Med Prim Care. 2020;9(8):3820-55. doi:10.4103/jfmpc.jfmpc_498_20

33. Talaat W, El-Wazir Y. The El-Tal El-Kebir story: an example of social accountability from Egypt. Med Teach. 2012 May 28;34(5):354-60. doi:10.3109/0142159X.2012.663950 